\title{
A Piece of Music as a Result of the Artistic Research
}

Eka Chabashvili

Vano Sarajishvili Tbilisi State Conservatoire, Tbilisi, Georgia

ARTICLE INFO

Keywords:

Idea

Inspiration

Intuition

Piano

Rational

\begin{abstract}
In the late 20th and 21st centuries, implementation of artistic research into the educational system has become increasingly intensive, both in the field of art as well as in the fields where arts collaborate with sciences. The subject of the paper is artistic research in the musical arts; how valuable is a piece of music created as a result of research from an artistic and scientific standpoint? The purpose of our study is to identify common and distinctive features of two different types of creative processes. To determine this, we use empirical and comparative research methods. To solve a scientific problem, we set a task - to compare the process of creating a piece with the process of artistic research, which results into a musical work. As artists describe their own creative process best of all, the paper is based on creative experience of Eka Chabashvili - the author of the current paper - as a composer. Two of her works are selected to describe the course and sequence of events that occurred in consciousness during their creation. The artistic process is divided into three main stages: 1) Source of inspiration and formation of the idea; 2) Transformation of the idea into musical notion and projection; 3) Materialization of the musical idea - its realization. Both compositions represent the combination of different components of artistic and technical ideas. Intuitive and rational tasks interchange with each other. The paper aims to determine the intuitive and rational ways of constructing musical concept.
\end{abstract}

\section{Introduction}

Art is seen as the ability to change the world, not by money or force, but by orientation, by radically transforming the "sensible," or sensory, reality of the eye, ear, taste, touch and smell, which unavoidably results in a change in ideas, understanding and insight. It may be about distancing, it may be about getting closer; sometimes it is irony or camp, sometimes it is a serious attempt to find illuminating concepts and their verbalisations and sometimes it is the need to create new myths or just tell stories (Hannula et al., 2014, p. x).

Art and literature have always been, and will always be, an authentic alternate chronicler, or even a detector and prophet of potential novelty. Truth can be read in art either directly or metaphorically, as it is genuinely evocative of the reality of the epoch in which the author lives and creates artworks. So why could not a genius artwork be considered equal to a scientific research?

The exact recipe for the creation and interpretation of a genius piece of music has not been found to this day, and it still remains a secret for musicologists. In the late 20th and 21st

* Corresponding author E-mail address: ekachabashvili@hotmail.com 
centuries, implementation of artistic research into the educational system has become increasingly intensive, both in the field of art as well as in the fields where arts collaborate with sciences. Though, as E. Lilja (2012) states, "Good" art is not the same as good artistic research. Good artistic research is not the same as "good" art (p.71).

Our research subject is artistic research in the musical arts; the research question is - to study the process of creating a work of art.

On one hand, the musical creative process is the source of the product that subsequently becomes the subject of musicological research; on the other hand, the artistic research process is the source of the creative product that represents the research outcome.

\section{Methods}

Thus, the aim of our study is to identify common and distinctive features of two different types of creative processes. To determine this, we used empirical and comparative research methods. To solve the scientific problem, we set a task - to compare the process of creating a piece with the process of artistic research, which results into a musical work. The paper describes both processes of creating a work of art and offers a comparative analysis which led us to some conclusions.

\section{Results}

As you know, no one can describe the creative process better than the author himself, so I decided to use my own creative experience as a composer. This was not easy, since the accuracy of current events and their detailed sequence is rather arbitrary, especially if this applies to that part of the process when intuitive source is activated. As it turns out, in this case things develop outside of time and space, and the sequence is difficult to be defined.

As a result of my observations, I categorize a sequence of events in two creative processes:

I. a musical work is created as a work of art;

II. a musical work is a result of artistic research (intended to become a source of knowledge).

For research, I selected two of my works to describe the course and sequence of events that occurred in consciousness during their creation. I tried to determine the intuitive and rational ways of constructing a musical concept.

I divided artistic process in three main stages for description:

- Source of inspiration and formation of the idea;

- Transformation of the idea into musical notion and projection;

- Materialization of the musical idea - its realization.

\section{Multimedia work "Bio-rhythms" for piano and two video installations ${ }^{1}$ :}

The first installation represents a photo-collage of Rodin's sculptures, accompanied by a poem of Georgian poet Besiki; the other broadcasts the "live" shooting of pianist's hands.

\section{Table 1}

Source of inspiration and formation of the idea

\begin{tabular}{ll}
\multicolumn{1}{c}{ Intuitive } & Rational \\
\hline When I visited Rodin's museum in Paris, in 2006, I & \\
got inspired by his sculptures, especially by "The & \\
Cathedral" (1908, Stone) which represents two right & \\
hands belonging to two different figures. Impressed & \\
by these hands, I got the idea to compose a piece & \\
which will express the feeling of the "sexual" energy &
\end{tabular}

\footnotetext{
${ }^{1}$ The link of the video-recording of the piece: https://www.youtube.com/watch?v=rcLp3tjqGng
} 
coming from the sculpture.

In 2014, a pianist Nino Jvania asked me to compose a piano piece inspired by works of K. Stockhausen for the concert to be held in New-York.

I have decided to express through music the intimate As the source of inspiration was chosen Stockhausen's relationship between a man and a woman, described from a woman's standpoint. Klavierstück XIV (from his opera Montag aus Licht) representing Conception of Eve with Piano Piece.

I have decided to combine music with sculpture, choreography, poetry and cinematography and make Based on all those ideas mentioned above, the tall of them musical sources.

\section{Table 2}

Transformation of the idea into musical notion and projection

\begin{tabular}{ll}
\multicolumn{1}{c}{ Intuitive } & \multicolumn{1}{c}{ Rational } \\
\hline $\begin{array}{l}\text { I got the idea to enrich piano performance with } \\
\text { choreographic elements. }\end{array}$ & \\
\hline $\begin{array}{l}\text { A pianist imitates the plastic of the sculpture in } \\
\text { motion and through these gestures produces sounds, } \\
\text { thus motion represents a musical element. }\end{array}$ & $\begin{array}{l}\text { imitate the plastic of sculpture by moving the ribbon. } \\
\text { She has slide the silk ribbon under and above the piano } \\
\text { strings in a particular rhythm, producing sounds. }\end{array}$ \\
$\begin{array}{ll}\text { The video-installation - the analogy of the musical } \\
\text { form - leads the dramaturgical line of the whole } \\
\text { piece; the pianist has to follows it. The tempo and the video-installation consisting of Rodin's } \\
\text { rhythm of the video editing imitates the rhythmic } \\
\text { of acceleration of the frames in order to express the } \\
\text { dynamic of the sexual act. }\end{array}$ & $\begin{array}{l}\text { orgasm. } \\
\text { The text of a poem "Tano-Tatano" by a Georgian }\end{array}$ \\
$\begin{array}{l}\text { poet Besiki, passionately describing the beauty of a the text of Besiki in the culminating moment } \\
\text { promotes the accumulation of energy. The recorded text } \\
\text { female body, is treated as a musical material. }\end{array}$ & $\begin{array}{l}\text { also brings into instrumental music an element of } \\
\text { electronic music. }\end{array}$ \\
\hline
\end{tabular}

Table 3

Materialization of the musical idea - its realization

\begin{tabular}{ll}
\multicolumn{1}{c}{ Intuitive } & \multicolumn{1}{c}{ Rational } \\
\hline $\begin{array}{l}\text { Live video-installation is concentrated on the } \\
\text { hands of the pianist, which time to time appear } \\
\text { on the screen of the prepared video projection, } \\
\text { creating another visual layer. }\end{array}$ & $\begin{array}{l}\text { From two video installations, one is static and the } \\
\text { the projector. }\end{array}$ \\
\hline & $\begin{array}{l}\text { Musical form consists of four parts (prelude, act, } \\
\text { orgasm, postlude) }\end{array}$ \\
\hline $\begin{array}{l}\text { I collected musical material: intonation, analogy } \\
\text { of harmony, rhythmical figurations, timbral } \\
\text { effects, and etc. }\end{array}$ & $\begin{array}{l}\text { Composition technique used in the piece - } \\
\text { sonority. }\end{array}$ \\
\hline $\begin{array}{l}\text { Music was visualized - notated using elements } \\
\text { of traditional and graphical notation. }\end{array}$ & $\begin{array}{l}\text { I used } 4 \text { staves - 2 for piano strings, } 2 \text { for keyboard } \\
\text { and geometrical shapes to notate particular sound } \\
\text { effects. }\end{array}$ \\
\hline $\begin{array}{l}\text { Many small but important details had to be invented in order to realize and materialize the idea into } \\
\text { the musical work. }\end{array}$
\end{tabular}

\section{Artistic research "The Piano of the 21st Century and its Future Perspectives"}

The outcome of the artistic research is an experimental interactive multimedia work "Has Piano Music come to an End?" for two pianos, one transformed piano and virtual piano orchestra that will be realized with the help of video-installations and live video broadcasting via social networks. The piece is being composed as a part of the artistic research project "The Piano of the 21st Century and its Future Perspectives" that is conducted by Eka Chabashvili and pianists Nino Jvania and Tamar Zhvania (2020) write: 
The piece reflects on one hand the evolution of the instrument through the centuries (this evolution will be described in a book accompanying the piece), and on the other hand the experiments conducted by the artistic researchers. The basic layer of the work is the sound of the $21^{\text {st }}$ century piano, while the other layers consist of allusions of various historical periods and styles related to the history of piano music - starting from 1732 when an Italian composer Lodovico Giustini composed the very first pieces - 12 Sonate de cimbalo di piano e forte exclusively for a new instrument, piano. The artistic researchers aim to display the panorama of the piano music from the perspective of the contemporary epoch" (p. 7).

\section{Table 4}

Source of inspiration and formation of the idea

\begin{tabular}{|c|c|c|c|}
\hline \multicolumn{2}{|c|}{ Conceptual Work } & \multicolumn{2}{|c|}{ Artistic Process } \\
\hline Intuitive & Rational & Intuitive & Rational \\
\hline $\begin{array}{l}\text { Source of Inspiration } \\
\text { source - K.Stockhausen's } \\
\text { (1993) words: } \\
\text { Piano music has come to } \\
\text { an end and something } \\
\text { quite different is coming. } \\
\text { I sense it clearly: with } \\
\text { the claviers made up to } \\
\text { this time, there is nothing } \\
\text { new to discover any } \\
\text { more (p. 138). }\end{array}$ & $\begin{array}{l}\text { A group of artistic } \\
\text { researchers - Nino Jvania, } \\
\text { Eka Chabashvili and } \\
\text { Tamar Zhvania aims to } \\
\text { analyze the stages of } \\
\text { development of piano } \\
\text { music in different epochs } \\
\text { and to reveal its future } \\
\text { perspectives. }\end{array}$ & $\begin{array}{l}\text { I defined the } 21 \mathrm{st} \\
\text { century as } \\
\text { Apocalypses of } \\
\text { piano. }\end{array}$ & $\begin{array}{l}\text { I am composing a large-scale } \\
\text { piano piece/performance, } \\
\text { which reflects the evolution } \\
\text { of the piano through the } \\
\text { centuries. }\end{array}$ \\
\hline $\begin{array}{l}\text { We aim to analyze } \\
\text { characteristics of piano } \\
\text { performance in various } \\
\text { musical movements. }\end{array}$ & $\begin{array}{l}\text { We study the structure of } \\
\text { the piano and its changes } \\
\text { in different epochs. }\end{array}$ & $\begin{array}{l}\text { I intend to use } \\
\text { various tuning } \\
\text { systems. }\end{array}$ & $\begin{array}{l}\text { We intend to visit museums } \\
\text { of musical instruments to } \\
\text { record pieces performed on } \\
\text { authentic instruments in } \\
\text { order to include the } \\
\text { recordings in our piano } \\
\text { piece/performance } \\
\text { allusions or collages. }\end{array}$ \\
\hline & & $\begin{array}{l}\text { I got an idea to use } \\
\text { a virtual piano } \\
\text { orchestra. }\end{array}$ & $\begin{array}{l}\text { Virtual piano orchestra will } \\
\text { be realized with the help of } \\
\text { video-installations and live } \\
\text { video broadcasting via social } \\
\text { networks; we intend to } \\
\text { engage listeners in } \\
\text { performance. }\end{array}$ \\
\hline
\end{tabular}

Table 5

Transformation of the idea into musical notion and projection

\begin{tabular}{|c|c|c|c|}
\hline \multicolumn{2}{|c|}{ Conceptual Work } & \multicolumn{2}{|c|}{ Artistic Process } \\
\hline Intuitive & Rational & Intuitive & Rational \\
\hline & $\begin{array}{l}\text { We intend to analyse } \\
\text { characteristics of various } \\
\text { piano performing schools. }\end{array}$ & $\begin{array}{l}\text { I plan to engage } \\
\text { various performing } \\
\text { stiles in the piano } \\
\text { piece/performance. }\end{array}$ & $\begin{array}{l}\text { Pianists play the same } \\
\text { musical material in } \\
\text { different styles. }\end{array}$ \\
\hline $\begin{array}{l}\text { We aim to engage with } \\
\text { acoustic pianos, } \\
\text { avoiding any } \\
\text { employment of } \\
\text { technologies (except of } \\
\text { amplification) to modify } \\
\text { the piano sound. }\end{array}$ & $\begin{array}{l}\text { We intend to analyse the } \\
\text { historical sequence of } \\
\text { events. }\end{array}$ & $\begin{array}{l}\text { The basic layer of the } \\
\text { piano piece is the } \\
\text { sound of the } 21 \mathrm{st} \\
\text { century piano. }\end{array}$ & $\begin{array}{l}\text { I create a composition } \\
\text { draft (number of layers, } \\
\text { orchestration, etc.) }\end{array}$ \\
\hline $\begin{array}{l}\text { We intend to display the } \\
\text { panorama of the piano }\end{array}$ & $\begin{array}{l}\text { We plan to choose key } \\
\text { works from piano music }\end{array}$ & & $\begin{array}{l}\text { The basic layer of the } \\
\text { work is the sound of the }\end{array}$ \\
\hline
\end{tabular}




\begin{tabular}{llll}
\hline $\begin{array}{l}\text { music from the } \\
\text { perspective of } \\
\text { contemporary epoch. }\end{array}$ & literature. & $\begin{array}{l}\text { We plan to create a } \\
\text { modified/transformed } \\
\text { piano }\end{array}$ & $\begin{array}{l}\text { 21st century piano, while } \\
\text { the other layers consist of } \\
\text { allusions of various } \\
\text { historical periods and } \\
\text { styles related to the } \\
\text { history of piano music. }\end{array}$ \\
\cline { 3 - 4 } & & $\begin{array}{l}\text { We plan to conduct } \\
\text { experiments with the } \\
\text { piano and to process of } \\
\text { modification in relation } \\
\text { composing of musical } \\
\text { material }\end{array}$ \\
\hline $\begin{array}{l}\text { We will write verbal } \\
\text { instructions and } \\
\text { explanations of research } \\
\text { approach to the piano piece. }\end{array}$ & perbal text will be a \\
part of piano & $\begin{array}{l}\text { The philosophical tale } \\
\text { about the piano world will } \\
\text { be recited. }\end{array}$ \\
\hline
\end{tabular}

Materialization of musical idea and its realization - is the stage that will occur after the research is finished and it represents artistic process which is similar to the artistic process of composing piano piece "Biorhythms", but with different artistic decisions will be made.

\section{Discussion}

The Idea ${ }^{2}$ is a flash in our mind.

Ideas are usually construed as mental representational images of some objects. Ideas can also be abstract concepts that do not present as mental images (Audi, R., 1995, p.355).

Idea is regarded by the majority of philosophers as a fundamental ontological category of being. It is an indispensable feature of human to be able to create and grasp the meaning of ideas. Ideas are mostly born in a very spontaneous way, and they don't always demand a serious reflection. However, a new idea often serves as a source of inspiration for an innovation.

As a composer, I would like to describe my experience:

- $\quad$ Before I compose a piece, I am looking for ideas in my mind. Usually, the idea is born unexpectedly, but sometimes I need a lot of time to find it.

- I realize that ideas appear after impressions. Some feelings or emotions deriving from impressions inspire me and some impulses from the environment push my mind to imagine something. These imaginations are very individual - for example, inner visions of the sound, images, or associative connections between different things, and etc.

- These visions leave various emotions in the body which are transformed into a source of energy used to compose a work.

I agree with Samuel Johnson, who states that ideas are mental images or internal visual pictures. As such, they have no relation to words or the concepts, which are designated by verbal names (Boswell J., 1830, p. 384).

In my opinion, the first stage is a formation of the idea. The ideas are particular commands and information which we have to decode and to develop using our fantasy and knowledge. They intuitively appear in our brains after we get inspired. Inspiration is a power that pushes this informational signal to be translated in our mind into a concept/notion. The author does not feel the time needed for the formation of idea, because the process develops unconsciously and intuitively. As Stockhausen explains - Intuition has a very particular kind of speed (Maconie R., 2000, p. 125). It is one moment when the idea appears as a flash in the

2 The word idea comes from Greek i $\delta \varepsilon \varepsilon \alpha$ and it means "to see". Democritus formulated the word "idea" as a philosophical term. 
mind. The ideas could build the chain during the process of creation, and they could appear time to time until process is finished.

The processes of the second stage, taking place in the author's brain, is already on the border of rational and intuitive activities. They always interchange. The second stage is the process of composing music and it is very complicated, because the information signal has many ways of transformation. The choice depends on the "translator's" interests and skills of imagination and verbalization. The composer translates a lot of ideas into the language of music and collects musical material like assembling a puzzle. The second stage continues until author decides how to construct the dramaturgy of work. All result of the second stage, including verbalization, could be implemented on both intuitive and rational levels.

Then starts the third stage of the process - a way to realization - the projection of the author's imagination to make it clear for others. From this moment, composer looks for rational decisions to communicate and connect with the potential listeners.

Thus, how valuable is a piece of music created as a result of research from an artistic and scientific standpoint? It's hard to answer. However, the main purpose of the research - to create a new source of knowledge - must necessarily be fulfilled. When the creative process is used for research that has a purpose to create a new source of knowledge, the research outcome must serve the same purpose. It is still the subject of discussion among artistic researchers, whether this type of research can be considered as a source of knowledge:

"If we approach the issue from the point of view of the critique of knowledge, it is certain that the concentration on knowledge according to the programme of the Enlightenment has, to a certain extent, clarified, simplified and crystallized our view of how everything works. At the same time, it has removed from our vision a great number of phenomena, only because they cannot, for some reason, be introduced as objects of knowledge or as their part, as our view of knowledge is exclusive and restrictive. Exclusiveness and restrictiveness are what have given knowledge its special power: claims that cannot be either falsified or proven coherent with something that is certainly known do not qualify as knowledge." (Hannula et al., 2014, p.vii).

However, every valuable piece of music itself becomes a source of a new knowledge. By asking questions and answering them while composing or researching music, describing our actions verbally and demonstrating our own thoughts, even in the form of an essay, we create a source of substantiated knowledge. "Knowledge" is not a firmly established, stable item, but much more a stock of findings in flux, manifesting itself in various ways and changing depending upon the context (Caduff et al., 2010, p.105).

\section{Conclusion}

The processes of creating of a piece of music and artistic research are different, but the results are very similar. Both compositions analysed in the paper represent combination of different components of artistic or technical ideas; intuitive and rational tasks interchange with each other. In order to form a proper and final thought, the mind is going through a difficult cycle of processing information on the intuitive and rational levels.

The process of creating an artwork depends on the configurations of intuitive and rational decisions made in the mind of a person. The author is not obliged to think about the importance of the result, to prove "something" by his/her piece. Maybe it is because of similar attitude that rationality in art "only has relevance in the realm of technical ability". (Neirhaus G., 2015, p.171)

During the embodiment of the idea within the artistic research, the balance between the artist's intuitive and rational approaches changes. In this case, the artist no longer relies on intellectual reserve on the intuitive and subconscious level and pays special attention to the 
rational principles. However, each artist uses these principles in an individual way. The originality and uniqueness of an idea is determined by the fact that it can be expressed in alternative ways. When artistic research involves several researchers, the creative process becomes collective one, revealing new connections between intuition and rationality: for example, one's intuitive sense could serve as a rational source for the other; or, vice versa, one's rational thought could serve as a source of inspiration for the other; and etc.

The artistic research is another way of creating a work of art. Therefore, developing the methodology and establishing rules does not mean that we have to put the creative process into a framework. This approach to creating an artwork, where the role of the research process is quite significant, is a very common phenomenon in the 20th and 21st centuries. I assume, it is rather a type of thinking than a new form of research. I agree with the opinion that the artistic process equals to the scientific research process, but the artistic process has to be free. This privilege gives the art the power to do innovative and unbelievable things. As Willian Blake (1977) said: "It is the greatest of crimes to depress true art and science." (p.169)

\section{Acknowledgments}

This paper is an output of the research project Development of Artistic Research Methodology on the Example of Exploration of the Piano of the 21st Century and its Future Perspectives. The project, as well as this work is supported by Shota Rustaveli National Science Foundation of Georgia (SRNSFG) [grant number FR-18-4275].

\section{References}

Audi, R. (1995). Cambridge Dictionary of Philosophy. Cambridge University Press.

Blake, W. (1977). The Portable William Blake. Penguin.

Boswell, J., Edmond, M. (1830). The Life of Samuel Johnso., John Sharpe.

Caduff, C., Siegenthaler, F., Wälchli, T. (2010). Art and Artistic Research, Zurich University of the Arts, Scheidegger \& Spiess.

Hannula, M., Suoranta, J., \& Vaden, T. (2014). Artistic research methodology: Narrative, power and the public (2nd ed.). Peter Lang.

Jvania, N., Zhvania, T. (2020). Introducing Artistic Research in Georgia. Proceedings of The Worl Conference on Research in Social Science. Diamond Scientific Publication, 1-8.

Lilja, E. (2012). What is "good" in art? The artistic research dilemma. InFormation, Volume 1, No 1, Nordic Journal of Art and Research, 69-72. https://journals.hioa.no/index.php/information/article/view/218/236

Maconie, R. (2000). Stockhausen on Music, Marion Boyars Publishers.

Neirhaus, G. (2015). Patterns of Intuition, Springer.

Stockhausen, K. (1993). Clavier music 1992. Perspectives of New Music, 31(2), 136-149. 